\title{
Intrapulmonary Lipid Deposits in Children Treated or Not with Parenteral Nutrition
}

ORIGINAL

Valmin Ramos-Silva ${ }^{1,2}$, Jane S. Castello ${ }^{1}$, Luciene L. da Motta ${ }^{1}$, Janine Pereira da Silva ${ }^{2}$, Gustavo Carreiro Pinasco ${ }^{2}$, Sophia Cornbluth Szarfarc ${ }^{3}$, Patrícia Casagrande Dias de Almeida ${ }^{2}$, Júlia Viana Espinosa de Oliveira ${ }^{4}$, José Mauricio de Oliveira Massena ${ }^{2}$, Jose Paulo Ferreira Junior ${ }^{2}$, Katia Valeria Manhambusque ${ }^{2}$, Italla Maria Pinheiro Bezerra² ${ }^{2}$ Joel Alves Lamounier ${ }^{5}$

\section{Abstract}

Background: Reports on pulmonary lipid deposition after parenteral nutrition (PN) in children were based on small samples. Here we report the prevalence of pulmonary lipid deposition in 114 consecutive autopsied children from a pediatric intensive care unit, including neonates, lactants, preschool, school children and adolescents that used or not PN before death. The objective of this study is to evaluate whether there is an association between the intrapulmonary deposition of fat and the use of lipid infusion in total parenteral nutrition in children.

Methods: All 114 autopsied children (January 1998 through December 2001) from the Intensive Care Unit of the Childrens's Hospital in Vitoria, ES, Brazil (50 that received PN before death and 64 that did not receive PN). Pulmonary lipid deposit was investigated in frozen sections of two fragments of each lung (peripheral and near the hylus) stained by Oil Red $\mathrm{O}$.

Results: Intrapulmonary lipid deposition was observed in $47 \%$ (54/114) of children. PN increased significantly the frequency of pulmonary lipid: $70 \%(35 / 50)$ in the group treated with PN and $29.6 \%$ $(19 / 64)$ in the non-treated group $(p=0.000)$. This difference persists significant if we consider separately the neonates and the children 29 days up to 15 years old (13/22) (59.1\%) and 22/28 (78.6\%) respectively in neonates and in non neonates).

Conclusion: Results demonstrated: (a) pulmonary lipid deposits are frequent in children dead at Intensive Care Unit; (b) in the group not
1 Children's Hospital N. S. da Glória, Vitória, ES, Brazil.

2 School of Sciences of Santa Casa de Misericórdia de Vitoria. EMESCAM, Brazil.

3 Nutrition Department of Public Health of the University of São Paulo, Brazil.

4 School of Medicine, Federal University of Espírito Santo, Brazil.

5 Graduate Program in Health Sciences, Federal University of São João Del Rei-West Campus Center, Divinópolis, Brazil.

Contact information:

Valmin Ramos-Silva.

Address: Avenida Estudante José Julio de Souza, 3120/602. Praia de Itaparica, Vila Velha, ES. CEP 20102-010.

झvalmin.ramos@emescam.br

झ valmin.silva@gmail.com 
treated with PN the frequency of lipid deposits was significantly higher in children older than 28 days than in neonates; (c) parenteral nutrition increased significantly the risk for pulmonary lipid deposition both in neonates and children older than 28 days.

\section{Keywords}

Pulmonary Lipid, Parenteral

Nutrition, Children.

\section{Introduction}

Lipid emulsions for parenteral use are complex solutions containing emulsifying agents and different concentrations of fat acids, glycerol, phospholipids and tocopherol, that have been used in clinical practice since 30 years ago [1]. The emulsifying agents can induce cellular injury because the reduction of the surface tension they produce on the cells. In addition they can increase the space between the lipids molecules in cell membrane, increasing the permeability and inducing lipid dispersion and cytolysis [2]. The introduction of new intravenous fat emulsions from oil of olives, fish and soy, reduced the incidence of pulmonary embolism, this is also a possible complication [3].

Although used as safe intervention when correctly indicated, lipid emulsions has been linked to the origin of pulmonary lipid deposition in children. Pulmonary fat deposition after parenteral nutrition in children has been reported in the lumen of pulmonary artery $[4,5,6]$ and alveolar capillaries [4, $6-9,10]$, in the cytoplasm of alveolar macrophages [4, 6, 8, 10-12] and alveolar epithelial cells [11], in septal macrophages, in bronchial chondrocytes and other interstitial cells [13]. Similar deposits has been reported in rabbits treated with homologous fat from adipose tissue [14], and in rats $[15,16]$ and pigs [17] treated with intravenous lipid emulsions.

The objective of this study is to evaluate whether there is an association between the intrapulmonary deposition of fat and the use of lipid infusion in total parenteral nutrition in children

\section{Methods}

\section{Samples}

This is case-control, where they compared lung fragments obtained from autopsies performed on children parts treated with parenteral nutrition (cases) and their controls who did not receive parenteral nutrition with lipid emulsion. Fifty children received parenteral nutrition and 64 did not receive this treatment and formed a control group. All the autopsies were performed up to 12 hours after death, after the parents' formal and signed agreement.

\section{Parenteral nutrition}

The total parenteral nutritional solution with $20 \%$ lipid emulsion, 10\% aminoacids, glucose, sodium chloride, potassium chloride, potassium phosphate, calcium gluconate and magnesium sulphate, was continuously infused by an infusion pump during 24 hours. The lipid emulsion contained soy bean oil, long chain fatty acids, mainly unsaturated, median chain fatty acids (60\% caprilic acid and $40 \%$ capric acid), egg lecithin, glycerol, sodium oleate, alpha-tocopherol and linoleic and alpha-linolenic acids. The initial dose of lipid emulsion was $0.5 \mathrm{~g} /$ $\mathrm{kg} / 24 \mathrm{~h}$, with increasing of $1 \mathrm{~g} / \mathrm{kg} / 24 \mathrm{~h}$ up to $3,5 \mathrm{~g} /$ $\mathrm{kg} / 24 \mathrm{~h}$. To reduce the peroxidation induced by light, photo-protected devices were used for infusion in all neonates that were under photo-therapy. The maximum lipid infusion used was $0.17 \mathrm{~g} /$ $\mathrm{kg} /$ hour and heparin was not added to the infused solution. 


\section{Detection of pulmonary lipid depositions}

From each case two $4 \%$ formalin fixed fragments of each lung, one from the area near the hylus and the other from the periphery, containing the visceral pleura, were used. The lung fragments were washed in tap water for two hours, mounted in a cryostat with inclusion medium (Tissue Freeze Medium, für Laborgebrauch, Berlin) and 5 um thick sections were obtained. The sections were mounted on slides previously coated with $20 \%$ human serum albumin and dried in a $55^{\circ} \mathrm{C}$ oven during five minutes. Lipid detection was performed by staining for 15 minutes with a saturated solution of Oil Red O in isopropanol, after filtration through filter paper. After staining the sections were washed in 50\% isopropanol and mounted under cover-slip with an aqueous mounting media (Aquatex Merck). The histopathology analysis was performed in the Pathology Laboratory of HINSG by the author and revised by two other pathologists.

\section{Clinical and anatomical data}

The data about age, gender, and body weight, time of hospitalization, medicine used and clinical and anatomical diagnosis were retrieved and reviewed, from the clinical and autopsy files.

\section{Statistics analysis}

For statistical analysis the Statistical Package for Social Sciences, 11.0, (Chicago IL, USA) was used. Descriptive statistics, association tests (qui square or Fisher exact test), Mann Whitney test for comparison of groups and log-linear logistic binary regression analysis were used when necessary. $P$ values lesser than 0.05 (two-sided tests), were considered significant.

This study was approved by the Research Ethical Committee from the Federal University of Minas Gerais.

\section{Results}

The data on age, gender, time of hospitalization, clinical manifestations, amount and duration of lipid infusion in children that received or not the lipid infusion, are summarized in Table 1. The two groups presented significant differences in regard to the

Table 1. Age, gender, duration of hospitalization, clinical diagnosis, therapeutic inteventions in 114 children treated or not with total parenteral nutrition, autopsied at the Children's Hospital NS Gloria in Vitória, ES, Brazil.

\begin{tabular}{|c|c|c|c|}
\hline \multirow{2}{*}{ Variables } & \multicolumn{2}{|c|}{ Total parenteral nutrition } & \multirow{2}{*}{$\mathrm{p}$} \\
\hline & Yes $(N=50)$ & No $(\mathrm{N}=64)$ & \\
\hline \multicolumn{4}{|l|}{ Gender (N\%) } \\
\hline Male & $28(56.0)$ & $32(50.0)$ & \multirow{2}{*}{0.65} \\
\hline Female & $22(44.0)$ & $32(50.0)$ & \\
\hline \multicolumn{4}{|l|}{ Age (days) } \\
\hline Mean \pm SD & $679.30 \pm 1395.92$ & $898.45 \pm 1728.24$ & \multirow{3}{*}{0.68} \\
\hline Median & 36 & 88 & \\
\hline Range & $1-5631$ & $1-5720$ & \\
\hline \multicolumn{4}{|c|}{ Body weigth (g ) } \\
\hline Mean \pm SD & $7687.80 \pm 10090.35$ & $10252.34 \pm 13145.71$ & \multirow{3}{*}{0.175} \\
\hline Median & 3600 & 4555 & \\
\hline Range & $1000-50000$ & $510-62000$ & \\
\hline \multicolumn{4}{|c|}{ Hospitalization (days) } \\
\hline Mean \pm DP & $14.12 \pm 13.52$ & $3.76 \pm 3.48$ & \multirow{3}{*}{$<0.00$} \\
\hline Median & 10 & 2.5 & \\
\hline Range & $1-71$ & $1-18$ & \\
\hline \multicolumn{4}{|c|}{ Total lipid infusion (g/kg) } \\
\hline Mean \pm SD & $13.92 \pm 17.81$ & - & \multirow{3}{*}{-} \\
\hline Median & 7.50 & - & \\
\hline Range & $1-86$ & - & \\
\hline \multicolumn{4}{|c|}{ Time of lipid infusion (days) } \\
\hline Mean \pm SD & $7.46 \pm 7.36$ & - & \\
\hline Median & 5 & - & \\
\hline \multicolumn{4}{|l|}{ Range } \\
\hline \multicolumn{4}{|c|}{ Clinical Diagnosis (N\%) } \\
\hline Sepsis & $40(80.0)$ & $41(64.1)$ & 0.098 \\
\hline Pneumonitis & $21(42.0)$ & $18(28.1)$ & 0.177 \\
\hline Prematurity & $13(26.0)$ & $4 \quad(6.2)$ & 0.008 \\
\hline $\begin{array}{l}\text { Congenital } \\
\text { heart disease }\end{array}$ & $10(20.0)$ & $15(23.4)$ & 0.832 \\
\hline Enterocolitis & $6(12.0)$ & $4(6.3)$ & 0.457 \\
\hline
\end{tabular}




\begin{tabular}{|l|c|c|c|}
\hline \multirow{2}{*}{ Variables } & \multicolumn{2}{|c|}{ Total parenteral nutrition } & \multirow{2}{*}{$\mathbf{p}$} \\
\cline { 2 - 3 } & \multicolumn{1}{|c|}{ Yes (N=50) } & No (N=64) & \\
\hline $\begin{array}{l}\text { Clinical Diagnosis (N\%) } \\
\text { Acute renal } \\
\text { failure }\end{array}$ & $5(10.0)$ & $7(10.9)$ & 1.000 \\
\hline $\begin{array}{l}\text { Cardiac failure } \\
\text { Asphyxia }\end{array}$ & $3(6.0)$ & $3(4.7)$ & 1.000 \\
\hline $\begin{array}{l}\text { Therapeutic interventions } \\
\text { Vasoactive } \\
\text { drugs }\end{array}$ & $4(2.0)$ & $7(10.9)$ & 0.138 \\
\hline $\begin{array}{l}\text { Blood } \\
\text { derivates }\end{array}$ & $48(96.0)$ & $59(92.2)$ & 0.995 \\
\hline
\end{tabular}

time of hospitalization and in the frequency of premature neonates. The age distribution among the two groups was similar if we consider the frequency of neonates or children 29 days up to 15 years old (respectively 22 and 28 in parenteral nutrition treated group and 25 and 39 in non treated group $(p=0.7340)$.

The overall frequency of intrapulmonary lipid deposition was 47\% (54/114). However parenteral nutrition increased significantly the frequency of lipid deposition in the lungs that was 70\% (35/50) in the group treated with parenteral nutrition and $29.6 \%$ $(19 / 64)$ in the non-treated group $(p=<0.001)$. This difference persists significant if we consider separately the neonates and the children 29 days up to 15 years older (Table 2 ).

When we compare the frequency of lipid deposits in the group not treated with parenteral nutrition, the frequency of lipid deposits are higher in children older than 29 days (1/24) (4.1\%) and 18/21 (46.1\%), respectively in neonates and children older than 29 days; $p=<0.001$ ). This difference was not significant in the group that received parenteral nutrition (13/22) (59,1\%) and 22/28 (78,5\%), respectively in neonates and non neonates $(p=$ 0.237).

In both groups lipid deposition was observed in alveolar and septal macrophages, and in the lumen or wall of blood vessels (Figure 1). The frequency of lipid deposits in each lung fragment (from periphery or central) was similar, as demonstrated by the Mc-
Table 2. Frequency of intrapulmonary fat deposition in 114 neonates and children treated or not with total parenteral nutrition, autopsied at the Children's Hospital NS Glória in Vitória ES, Brazil.

\begin{tabular}{|c|c|c|c|c|c|}
\hline \multirow{2}{*}{\multicolumn{2}{|c|}{ Groups }} & \multicolumn{2}{|c|}{$\begin{array}{l}\text { Parenteral } \\
\text { nutrition }\end{array}$} & \multirow{2}{*}{$\begin{array}{c}\text { OR } \\
(95 \% \mathrm{Cl})\end{array}$} & \multirow[t]{2}{*}{$p$} \\
\hline & & Yes & Yes & & \\
\hline \multicolumn{6}{|l|}{ All children } \\
\hline \multirow{2}{*}{$\begin{array}{l}\text { Intrapulmonary } \\
\text { lipid }\end{array}$} & Present & 35 & 19 & \multirow{2}{*}{$\begin{array}{c}5.53 \\
(2.29-13.53)\end{array}$} & \multirow{2}{*}{$<0.001^{*}$} \\
\hline & Absent & 15 & 45 & & \\
\hline \multicolumn{6}{|c|}{ Neonates } \\
\hline \multirow{2}{*}{$\begin{array}{l}\text { Intrapulmonary } \\
\text { lipid }\end{array}$} & Present & 13 & 1 & \multirow{2}{*}{$\begin{array}{c}34.6 \\
(3.65-819.14)\end{array}$} & \multirow{2}{*}{$0.0001^{*}$} \\
\hline & Absent & 9 & 24 & & \\
\hline \multicolumn{6}{|c|}{ Children $>29$ days up to $15 \mathrm{yr}$} \\
\hline \multirow{2}{*}{$\begin{array}{l}\text { Intrapulmonary } \\
\text { lipid }\end{array}$} & Present & 22 & 18 & \multirow{2}{*}{$\begin{array}{c}4.28 \\
(1.27-15.03)\end{array}$} & \multirow{2}{*}{$0.0157^{*}$} \\
\hline & Absent & 6 & 21 & & \\
\hline
\end{tabular}

Figure 1: Intrapulmonary fat deposits in children treated with lipid emulsions in parenteral nutrition.

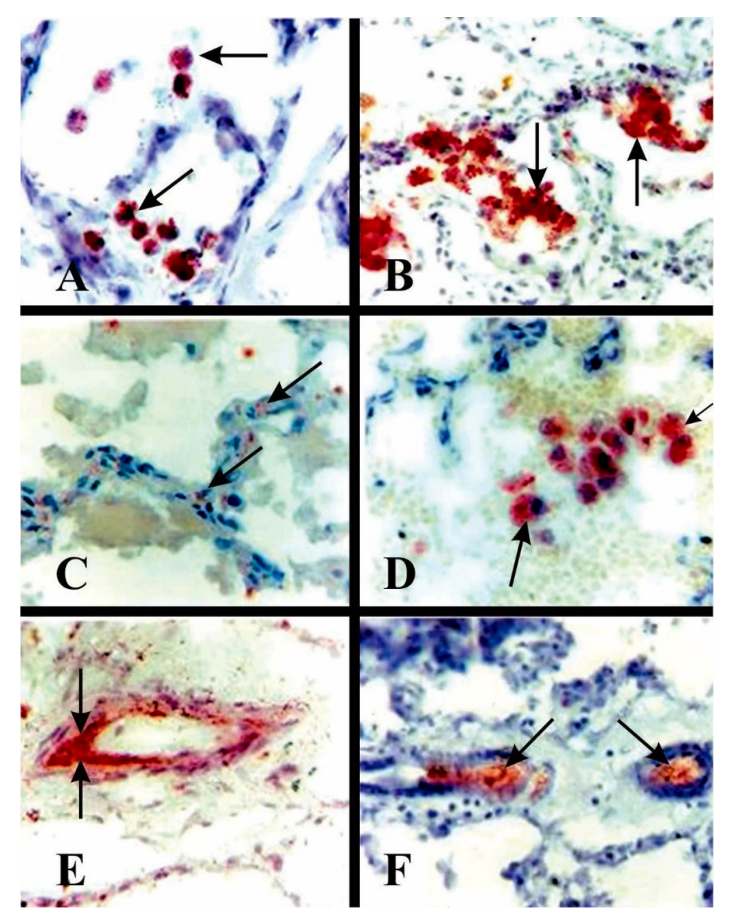

A: fat located in alveolar macrophages (red oil 40x); B: Fat located in alveolar macrophages (red oil 40x); C: fat located in alveolar septa (oil red 40x); D: fat located in alveolar macrophages (red oil 40x); E: fat located in pulmonary vessel wall (red oil 40x); F: fat located in the pulmonary vessel inside (oil red 40x). 
Nemar test $(p=0.629)$ and by the Kappa index for concordance (Kappa $=0.691, p=0.0005)$. The topography of lipid deposition showed not relationship with the total parenteral nutrition, being similar in group that received or not the lipid infusion. Lipid deposition within septal or alveolar macrophages was significatively lower in neonates than in children 28 days up to 15 years old $(p<0.005)$.

\section{Discussion}

The sample we studied included neonates and children without significant differences in ages between the groups that received or not the lipid infusion. All cases had similar clinical and demographic characteristics and were submitted to similar therapeutic interventions, except the parenteral nutrition. However, the duration of hospitalization and the number of neonates were greater in the group treated with parenteral nutrition. By these reasons all the conclusions resulted from the comparison between these two groups may consider the caveats resulting the assumption that they are comparable.

Our results demonstrated that pulmonary lipid deposition was significantly more frequent in children that received lipid infusion, in comparison with children that not received parenteral nutrition. This observation confirms previous reports in which only neonates were included in the study $[9,12,13]$. In addition the results demonstrates that the frequency of lipid deposition was also significantly high in children older than 28 days treated with parenteral nutrition, in despite the higher frequency of lipid deposits in children not treated with parenteral nutrition int his group.

The great number of cases we report here enhance the idea that lipid infusion is in direct relationship with the pulmonary lipid deposition observed in children treated with parenteral nutrition. However, the mechanism of this lipid deposition is unknown. Experimental studies in rats and pigs demonstrated that intravenous lipid infusion may be a primary cause of pulmonary lipid deposition $[15,16,17]$. Resuscitation maneuver were frequently used in the two groups of children in this study. Bone fractures during these maneuvers may be responsible by lipid deposition [19]. Thus it is possible that the lipid infusion only increases the chance of pulmonary lipid deposits. The high frequency of fat deposits in lungs of children that not received total parenteral nutrition reinforces this hypothesis. Other authors suggested that pulmonary lipid deposition could be a post mortem phenomenon19. However, the high frequency of lipid in macrophages is an indicative that this lipid deposition occurred before death. Other admitted that in neonates and children with severe disease an unknown factor (C reactive protein?) would induce coalescence of lipoprotein after lipid infusion, with increase in size of lipid particles, which are filtered in the lungs [10]. The stress response would be such a factor in intrapulmonary lipid deposition, as observed in rabbits submitted to a vigorous stress [14].

The frequency of lipid deposition was similar in the periphery and in central lung fragments, in opposite of other observations in which the lipid deposition was reported more frequently in lung periphery [4, 12]. However, in these studies the authors did not comment about the sampling of lung fragments and probably the small number of cases they studied was the main cause of the difference observed. Levene et al $[9,10]$ and Shulman et al [13], that studied series of cases, did not report the topography (if periphery or central) of fat deposits they observed in the lungs.

\section{Conclusion}

Our results demonstrated that intrapulmonary lipid deposition is a frequent event in neonates and children that die at intensive care units being significantly higher in the group that received parenteral 
nutrition. It is possible that lipid infusion increases the risk for lipid coalescence initiated by stress in these severely ill patients, thus increasing the deposition of lipid droplets in lung tissues.

\section{References}

1. Waitzberg DL, Lotierzo PH, Logullo AF, Torrinhas RSMM, Pereira CCA. Emulsões lipídicas parenterais e os sistemas fagocíticos. Nutrição em pauta 2002;21-29

2. LeVeen HH, Giordano P, Spletzer J. The mechanism of removal of intravenously injected fat. Arch Surg 1961;83:311-21.

3. Pichler J, Biassoni L, Easty M, Irastorza I, Hill S. Reduced risk of pulmonary emboli in children treated with long-term parenteral nutrition. Clin Nutr. 2016 Mar 31. pii: S0261-5614(16)30004-8. doi: 10.1016/j.clnu.2016.03.016.

4. Barson AJ, Chiswick ML, Doig CM. Fat embolism in infancy after intravenous fat infusions. Arch Dis Child 1978;53:218-23.

5. Dahms BB, Halpin TC. Pulmonary arterial lipid deposit in newborn infants receiving intravenous lipid infusion. J Pediatr 1980;97:800-05.

6. Hulman G, Levene MI. Intralipid microemboli. Arch Dis Child 1986;61:702-03.

7. Friedman Z, Marks KH, Maisels MJ, Thorson R Naeye R. Effect of parenteral fat emulsion on the pulmonary and reticuloendothelial systems in the newborn infant. Pediatrics 1978; 61:694-98.

8. Hertel J, Tygstrup I, Andersen GE. Intravascular fat accumulation after Intralipid infusion in the low-birth-weight infant. J Pediatr 1982;100:975-76.

9. Levene MI, Wigglesworth JS, Desai R. Pulmonary fat accumulation after intralipid infusion in the preterm infant. Lancet 1980;18:815-19.

10. Levene MI, Batisti O, Wigglesworth JS, Desai R, Meek JH, Bulusu S, Hughes E. A prospective study of intrapulmonary fat accumulation in the newborn lung following intralipid infusion. Acta Paediatr Scand 1984;73:454-60.

11. Schröder $H$, Paust $H$, Schmidt R. Pulmonary fat embolism after intralipid therapy - a post-mortem artefact?. Acta Paediatr Scand 1984;73:461-64.

12. Puntis JW, Rushton DI. Pulmonary intravascular lipid in neonatal necropsy specimens. Arch Dis Child 1991;66:26-28.
13. Shulman RJ, Langston C, Schanler RJ. Pulmonary vascular lipid deposition after administration of intravenous fat to infants. Pediatrics 1987;79:99-102.

14. Harman JW, Ragaz FJ. The pathogenesis of experimental fat embolismo. Am J Path 1950;26:551-63.

15. Nordstran K, Eide TJ, Giercksky KE. Parenteral nutrition via the portal vein in rats. Acta Chir Scand 1987;153:93-98.

16. Aksnes J, Eide TJ, Nordstrand K. Pulmonary intravascular macrophages appear in rats after long-term administration of lipid emulsion and amino acid solution. APMIS 1998;106:68792.

17. Aksnes TA, Foerster A, Hovig T, Schmidith $H$, Nordstran K. Development of granulomas and vascular fibrocelular proliferations in the lungs of pigs receiving long-term lipidbased parenteral nutrition. APMIS 1994;102:623-32.

18. Hulman G. The patogenesis of the embolism. J Pathol 1995;176:3-9.

19. Allardyce DB. The postmortem interval as a factor in fat embolism. Arch Path 1971; 92:248-53.

\section{Publish in International Archives of Medicine}

International Archives of Medicine is an open access journal publishing articles encompassing all aspects of medical science and clinical practice. IAM is considered a megajournal with independent sections on all areas of medicine. IAM is a really international journal with authors and board members from all around the world. The journal is widely indexed and classified Q2 in category Medicine. 